\title{
Grammatical metaphor in academic texts of Indonesian students' thesis
}

\author{
Mahmudah $^{* 1}$, Hajrah $^{2}$, Arni Amir ${ }^{3}$, Muhamad Ahkam Arifin ${ }^{4}$ \\ 1,2,3 Universitas Negeri Makassar, Makassar, 90221, Indonesia \\ e-mail: ${ }^{* 1}$ mahudah.mahfud@unm.ac.id, ${ }^{2}$ hajrah@unm.ac.id, ${ }^{3}$ arniamir9@gmail.com \\ ${ }^{4}$ University of Melbourne, Melbourne, Australia \\ e-mail: arifinm@student.unimelb.edu.au
}

\begin{abstract}
The purpose of this research is to reveal the form and pattern of lexical shift either lexically or grammatically by (1) to describe the form of grammatical metaphor of academic text, and (2) to describe the pattern of lexical shift in academic texts. The type of this research is qualitative research using Functional Systemic Linguistic approach. The academic texts was analyzed using theory of M.A.K. Halliday. The data in this study are words, phrases, clauses, and sentences in academic texts that undergo lexical and sentence shifts. The data source in this research is thesis of Indonesian Language and Literature Study Program in the year of 2015. Data collection techniques are documentation, reading, and record technique. The results found forms of grammatical metaphor which include (1) nominalization, (2) groups of nouns, and (3) simplex phrases. The lexic shift patterns found in this study include: (1) verbs to nouns, (2) adjectives to nouns, (3) adverbs to nouns, and (4) nouns to nouns.
\end{abstract}

\section{Keywords:}

Grammatical; metaphor; academic texts

\section{INTRODUCTION}

Scientific work as a scientific essay, its form and presentation is demanded scientifically in order to foster a scientific ethos so that it not only makes the students as consumers of science, but also able to become a producer of thought and writing in the field of science. The general view that has evolved so far has been that the scientific work has characteristics such as simple, solid, objective, and logical. However, so far there has been no empirical evidence proposed to provide a sufficient linguistic explanation of this simple, concise, objective, and logical sense.

Therefore, the scientific of a scientific work into something that needs to be followed up so that the characteristics of a text is not only understood instinctively, but based on a particular data or theory that is the theory of Functional Systemic Linguistics to find the meaning of scholarly a scientific work or academic texts.

The type of this research is qualitative research which is studied by using Functional System Linguistic Theory M.A.K. Halliday. The data in this study are words, phrases, clauses, and sentences containing shifts of both shifts in the lexis level and shift in the sentence level. The data source is obtained from 
the thesis of the students of Language and Literature Program of Indonesia Year 2015. Data collection techniques used are the techniques of reading, and record techniques. The data analysis technique begins with data identification, data classification, data interpretation, and data descriptions.

\section{The Form of Grammatical Metaphor}

This paper describes the forms of grammatical metaphor in the thesis of an Indonesian students.

\subsection{Nominalization}

\section{Incongruent}

Literary works are the result of the imagination of a person who often presents a life colored by the attitude, background and belief of the writer.

\section{Congruent}

Literary works are the product of the imagination of a person who often presents something in life that is colored by the attitude, background and believed by the person who write.

In the data citation (1), the bolded word in ingkongruen is a noun that has undergone a shift from congruent expression. The word life is a form of nomination from the adjective of live. The word belief is a form of nomination from the verb believe. The writer is a form of nomination from the verb write.

Incongruent

The style of writing that is intended is ranging from the selection of words, sentence structure and the use of punctuation often used by the author as one way to make the literary work look attractive.

\section{Congruent}

The style of writing that is intended is ranging from choosing words, sentence structure and the use of punctuation is often used by writer who make up as one way to make the literary work look attractive.

The bolded word in incongruent is a noun word that has undergone a shift from congruent expression. The word writing is a shifting form of the word of write. The word election is a form of shifting from the elect word. The word usage is a form of shift from the word use. The composer word is a shift from the writing word.

Incongruent

Stylists by Leech \& Short refer to the definition of study of stiles, the study of the form of linguistic performance, especially those found in literary texts.

Congruent

Stylists by Leech \& Short refer to define the study of styles comprises the study of the form of language performance. Especially the performance of language in literary texts. 
In the data quote (18), the bolded word in incongruent is a noun hat has undergone a shift from congruent expression. Definition is a form of nomination from the verb of define. The word of study is a form of nomination from the word verb to study. The word linguistics is a form of nomination from the word noun language. The word literature is a form of nomination from the word noun letters.

\section{Incongruent}

This research is conducted to provide explanation to the public that actually research on stilistika not only examine the style of language alone, but also review about the signs of linguistics, the typical use of words and sentences as one method in stilistika to analyze the character of a person as Aminuddin (1995) argues that stylistic studies can also be used to describe the identity, characteristic of speaker, as well as the cultural and social life environment of his culture.

\section{Congruent}

This research activity is done to explain to the public that actually in researching stylistics not only study about the language only. Stylistics also examines the linguistic signs, characteristic in using words and sentences as one method in stylists to analyze character characters. Aminuddin (1995) also explains that study the stylistic can also be used to describe the identity, characteristic of the speaker, as well as the socio-cultural life environment.

The bolded word in incongruent expression is a noun word that has undergone a shift from congruent expression. The word research is a form of nomination from the word verb research. The explanation word is a form of nomination of the verb explain. The word use is a form of nomination of the verbs using. The word study is a form of nomination from the word verb to study. The word life is a form of nomination from the word adjective live.

\section{Incongruent}

The use of verbs by authors is intended to illustrate that Kejora is a woman [who has many activities and likes adventure].

\section{Congruent}

In using the verb, the person who write intends to describe the character of Kejora. The character of the Kejora is described as an active woman.

In incongruent expression is a noun word that has undergone a shift from congruent expression. The word use is a form of nomination of the word verbs using. The writer is a form of nomination from the word verb write. The word activity is a form of nomination from the word adjective active.

\subsection{Nominalization Group}

\section{Incongruent}

The use of the word" I "to show the familiarity between the writer and the reader, so there is no distance between them.

\section{Congruent}

The word 'I' is used to indicate the familiar condition between the person who write the story and the person who read the story so there is no distance between the two. 
The word use, the writer and the reader are words of the verb used, written and read. Familiarity which is a word that is from familiar adjectives. The four nominalized results are collected in one cluster. The shift is a form of shifting the level of the sentence into a group of nouns.

Incongruent

The cross-references in this study consist of categories such as reference, substitution and ellipsis, repetition and elegant variations.

\section{Congruent}

The cross-references on the results of study consist of several categories such as process referring to substitution and ellipsis, repeating processes and elegant variations.

The word of study, reference and repetition are the words of the verb of to study, to refer and to repeat. The three nominalized results are collected in one cluster. The shift is a form of shifting the level of the sentence into a group of nouns.

Incongruent

In the study, it illustrates that Kejora is a woman who admires beauty.

Congruent

The activity to study illustrates that Kejora is a woman who admires everything beautiful.

In the data citation (80), the study word is a word that is derived from the study verb and the word beauty is the word that is derived from the beautiful adjective. Both nominalized results are collected in one cluster. The shift is a form of shifting the level of the sentence into a group of nouns.

Incongruent

The courage and firmness possessed by Kejora are able to break the dominance of men in their lives.

\section{Congruent}

Kejora has a courage and firm nature. Courage and firmness of Kejora can break the domination of men in his life.

The word of courage and firmness is a word noun comes from adjective of courage and firm. Both nominalized results are collected in one cluster. The shift is a form of shifting the level of the sentence into a group of nouns.

\section{Incongruent}

The research results reveal that the uniqueness and distinctive style of the work is influenced by the socio-cultural and educational background of the writer. 


\section{Congruent}

The results of the study reveal that the unique features and unique characteristics and styles of the work are influenced by the sociocultural background and the educational process of the person who write.

The word uniqueness is a word derived from the unique adjective word, as well as the writer is noun that comes from verb of write. The results of the nomination are gathered in one cluster. The shift is a form of shifting the level of the sentence into a group of nouns.

\subsection{Simple Sentence}

\section{Incongruent}

All authors have different styles of authorship or characteristic.

\section{Congruent}

All authors have the characteristic of authorship. Each author has different writing styles

The sentence is a simplex phrase composed by two complex sentences such as the congruent expression quotation. The conjugate sentence pattern is $\mathrm{S}+$ $\mathrm{V}+\mathrm{O}[.$.$] . The sentence consists of the subject line of "all authors", verb$ "have", the object "writing style or authorship characteristic" is embedded with different "different" embeds to compress information.

\section{Incongruent}

Writing styles [which are meant starting from word selection, sentence structure and the use of punctuation] are often used by authors as a way to make the literary work interesting.

\section{Congruent}

Authors often use the writing style as one way to make literary works look interesting. Some of the writing styles include word selection, sentence structure and punctuation.

The sentence is a simplex phrase composed by two complex sentences such as the congruent expression quotation. The sentence pattern is $\mathrm{S}[.]+.\mathrm{V}+\mathrm{O}+$ C. The sentence consists of the subject line of the "writing style" embedded with "which is intended to be from word selection, sentence structure and the use of punctuation, "verb" often used "," author "object, and Complement" as one way of make the literary work look interesting ".

\section{Incongruent}

The author uses the word [meaning denotation] to describe the tightness of brotherhood [which is intertwined among the characters].

\section{Congruent}

The author uses the word denotation meaningless. The meaningful word denotation is used by the author to describe the tightness of brotherhood among the characters in the Geni Jora novel. 
In the data citation (36), the sentence is a simplex phrase composed by two complex sentences as in congruent expressions. The sentence compiler pattern is $\mathrm{S}+\mathrm{V}+\mathrm{O}[.]+.\mathrm{C}[.$.$] . The sentence consists of the subject line of the$ "author", the verb "use", the object "the word" embed "meaning denotation", and the description "to describe the tightness of the" embedded "brotherhood" intertwined among the characters ".

Incongruent

Repetition figure of speech is more used by authors to describe the character of the Kejora than the [other] masters.

"Majas are used by the person who made up the story to describe the character of the Kejora character. Major reps are more widely used than other masters to describe the character of Kejora.

The sentence is a simplex phrase composed by two complex sentences as in congruent expressions. The pattern of the compiler of the sentence ie $\mathrm{S}+$ $\mathrm{V}+\mathrm{O}+\mathrm{C}[.$.$] . The sentence consists of the subject line of "repetitive figure of$ speech", verb "more widely used", "author" object, Compliment" to describe the character of Kejora versus figure of speech", another "embed".

\subsection{Leksis Shift Pattern}

\section{Incongruent}

Literary works are the result of the imagination of a person who often presents a life colored by the attitude, background and the belief of the writer.

\section{Congruent}

"Literary works are the product of the imagination of someone who often presents something about life that is colored by attitudes, backgrounds and beliefs that are believed by person who write."

The noun of life means 'life state' is derived from the basic verb meaning "life in a state or in a certain way" as its source. The nomina of belief means 'true believe' derived from the word 'believe' (really comprehend). In noun of beliefs though derived from the word believe, but the meaning of beliefs related to the meaning believed to 'believe' based on the interpretation of the meaning between the source. The noun of writer is derived from write. But the writer's meaning relates to the word of write and 'composing a story' based on the source.'

\section{Incongruent}

The Geni Jora novel published by the Sun in 2004 is one of Abidah El Khalieqy's works and was the second winner of the 2003 Jakarta Arts Council Novel Writing Competition.

\section{Congruent}

One of Abidah El Khalieqy's works, the novel Geni Jora published by Matahari in 2004, won second place at the 2003 Jakarta Arts Council Novel Writing Competition.

The noun of winner means 'winning person' is derived from the verb of win means 'can defeat (enemy, rival') Based on the related meaning between the 
source then the word winner is not derived from the intransitive verb of win, but is derived from the transitive verb of win 'to succeed in getting something'.

Incongruent

Furthermore, in the substitution and ellipsis categories characterized by the replacement of a structure of other forms referring to the same referent and ellipsis is the reduction or abbreviation of the previously mentioned structural units.

The substitution and ellipsis categories are marked by replacing a structure of other forms. Referring to referents and ellipsis is to reduce or summarize the unit of structure as mentioned earlier. "

The noun of replacement means 'process, manner, and act of replacing derived from the noun means 'something that is a non-existent or missing exchanger. Based on the connection of meaning between the sources then the word of replacement is derived from the verb of replace meaning 'exchange (with others)'. Subsequently, the noun of reduction means process, means, the act of reducing is derived from adverbs less meaningful words 'not yet or not the same'. Based on the related meanings of the source then the word reduction is derived from the verb of reduce or 'take (cut) a part'. Furthermore, noun of summary means process, manner, act of abbreviating is derived from short word meaning 'concise adjective' (on story, speech, etc.). Based on the related meanings of the source then the word of summary is derived from summarize.

\section{DISCUSSION AND CONCLUSION}

Based on the results of the analysis and discussion can be concluded that the form of shifting metaphor in the thesis of students of Indonesian Language and Literature Program there are three, namely nominalization, noun groups, and simplex phrases. On the nominalization side, it is known that information compaction with lexical alteration is found in the thesis. Information compaction with nominalization is aimed at expressing knowledge more concisely and densely. From the point of view of nominalization, the texts contained in the thesis show the characteristics of scientifically ideational. On the side of the noun group is known that the compaction of information with the shift of the sentence level into a group of nouns are found in the thesis. The lexis cluster in the thesis tends to be a noun group, and many are concerned with the realization of meaning in an ideational way. On the side of the simplex sentence is known that the shift from several complex sentences into simplex sentences resulted in the compaction of meaning. Compression of meaning with the simplex phrase in the thesis shows scholarly characteristics both ideational and textual.

The pattern of lexical shift in the thesis of the students of the Indonesian Language and Literature Program is four from verbs to nouns, from adjectives to nouns, from adverbs to nouns, and from the nouns themselves. Based on the data analysis it is known that the lexical shift from verb to noun dominates in the thesis compared to the number of lexical shifts of the adjectives, adverbials, and nouns themselves. In general, it can be concluded that the thesis uses a lot 
of grammatical metaphor in incongruent expression. So it is clear in terms of grammatical metaphor, the thesis shows the characteristics of scholarship in an ideational and textual. Through the grammatical metaphor the content of the material presented becomes more compact, and textually, the delivery of matter involving the shift of the level also affects the different organizational arrangements at the group level of words or sentences. The study of grammatical metaphors on academic texts, especially student thesis, has an important influence in the development of the study of language. This kind of research can add insight and knowledge especially for students. Expected by the existence of such research can be a reference and reference and become a motivation for further researchers.

\section{BIBLIOGRAPHY}

Akhlada, Nahda. 2014. Pergeseran Bentuk dan Makna dalam Terjemahan Komik L'Agent 212 (Dari Bahasa Prancis ke Bahasa Indonesia). Universitas Negeri Yogyakarta.

Alwi Hasan, dkk. 2010. Tata Bahasa Baku: Bahasa Indonesia Edisi Ketiga. Jakarta: Pusat Bahasa dan Balai Pustaka.

Chaer, Abdul. 2007. Linguistik Umum. Jakarta: Rineka Cipta.

Endraswara, Suwardi. 2011. Metodologi Penelitian Sastra. Yogyakarta: CAPS.

Halliday, M.A.K. 1994. An Introduction to Functional Grammar. London: Edward Arnold.

Halliday, M.A.K. 1994. Bahasa, Konteks, dan Teks: Aspek-Aspek Bahasa dalam Pandangan Semiotik Sosial. Yogyakarta: Gadjah Mada University Press.

Pusat Bahasa. 2012. Kamus Besar Bahasa Indonesia. Jakarta: Gramedia Pustaka Utama.

Reski, Sri. 2015. Analisis Stilistika dalam Novel Geni Jora Karya Abidah El Khalieqy. Skripsi Universitas Negeri Makassar.

Ria, Tina, Zen. 2014. Metafora Gramatikal Pada Teks Terjemahan Buku Biologi Bilingual. Universitas Sumatera Utara.

Wiratno Tri, dkk. 2014. Bahasa Indonesia: Ekspresi Diri dan Akademik untuk Perguruan Tinggi. Jakarta: Pembelajaran dan Kemahasiswaan. 